\title{
PERBEDAAN TINGKAT KEPUASAAN PASIEN UMUM DAN PASIEN DENGAN BADAN PENYELENGGARA JAMINAN SOSIAL
}

\author{
Harris Rambey ${ }^{1}$, Beni Satria², Marice Simarmata², Anggi Isnani \\ Parinduri2, Ester Ariani Tarigan² \\ Institut Kesehatan Medistra Lubuk Pakam \\ Jl. Sudirman No.38 Petapahan Lubuk Pakam \\ Kabupaten Deli Serdang Sumatera Utara \\ e-mail: harrisrambey@medistra.ac.id \\ DOI $10.35451 / \mathrm{jkg} . v 3 i 2.692$
}

\begin{abstract}
Quality health care was often associated with satisfactory health care. The patient's satisfaction with the health service was the level of one's feelings after comparing the results received with expectations. Patient satisfaction on health service can be seen tangible, responsiveness, reliability, assurance, and attention (empathy). This study aims to determine differences in patient satisfaction level of social insurance provider body with general patients at Grandmed Hospital Lubuk Pakam 2017. This type of research was quantitative research is comparative. The population in this research are all inpatients of Grandmed Hospital Lubuk Pakam as much as 324 people, purposive sampling technique, data collection method by interviewing indirectly by used questionnaires, data analysis using T-Independent test. Based on the result of the research, it was known that there was difference of patient satisfaction level of social insurance provider body with general patient based on physical evidence (tangible) with $p$ value $=0,002$, reliability with $p=0,005$, responsiveness with $p=0,007$, Based on assurance with $p=0,002$, based on empathy (empathy) with $p=0,006$. It was advisable for the nursing staff of the grandmed hospital to be able to perform the service very well so that the patient was satisfied with the existing services and raises the patient's interest to return if they are sick.
\end{abstract}

Keywords: Patient Satisfaction, BPJS, Patient General 


\section{PENDAHULUAN}

Manusia memiliki keinginan untuk sehat. Keadaan sehat menjadi kehendak semua pihak termasuk perorangan, keluarga, dan masyarakat. Untuk dapat mewujudkan keadaan sehat tersebut banyak hal yang perlu dilakukan. Salah satu diantaranya yang dinilai mempunyai peranan yang cukup penting adalah menyelenggarakan pelayanan kesehatan (Allo, 2013).

Badan Penyelenggara Jaminan Sosial (BPJS) merupakan suatu organisasi untuk penyelenggaraan program Sistem Jaminan Sosial Nasional (SJSN). Menurut Fidela (2015) layananan BPJS pada tahun 2014 belum maksimal dan masih rapor kuning.

Pada tahun 2015 peserta BPJS Kesehatan di Indonesia sebanyak 137.743.318 jiwa (BPJS Kesehatan, 13 Februari 2015). Jumlah peserta BPJS Kesehatan dipropinsi Sumatera Utara yaitu 6 juta jiwa, dengan peserta di kota Medan sejumlah 1.700 .000 jiwa (Kemenkes RI, 2014).

Pelayanan kesehatan yang membuat pasien puas bisa dikatakan sebagai pelayanan kesehatan yang bermutu. Perbandingan hasil perasaan seseorang yang diterima dengan harapannya merupakan kepuasaan pasien terhadap pelayanan kesehatan. Pasien akan merasa puas jika pelayanan kesehatan yang diberikan sesuai dengan harapannya dan sebaliknya apabila pasien tidak puas jika pemberian pelayanan kesehatan tidak sesuai dengan harapannya. Kepuasan pasien pada pelayanan kesehatan dapat dilihat bukti fisik (tangible), daya tanggap (responsiveness), kehandalan (reliability), jaminan (assurance), dan perhatian (empathy) (Hidayat, 2010).

Beberapa indikator kepuasan pasien dirumah sakit yang bersifat objektif yaitu keluhan pasien atau keluarga, kritik pasien pada kolom surat pembaca, dugaan mal praktek, dan laporan dari perawat. Menurut Sabarguna (2010) ketidakpuasan pasien ada hubungannya dengan sikap dan prilaku tenaga kesehatan seperti dokter dan perawat terlambat memberikan pelayanan, sulitnya bertemu dengan dokter, dokter tidak ramah dan kurang dalam memberikan informasi kesehatan, dan lain-lain.

Berdasarkan hasil survey pendahuluan didapatkan data bahwa jumlah pasien rawat jalan periode Januari sampai dengan November 2016 sebanyak 151.680 orang dan rawat inap 20.357 orang. Dari wawancara yang dilakukan terhadap 10 (sepuluh) orang pasien BPJS dan pasien umum didapatkan adanya keluhan ketidakramahan petugas saat memberikan pelayanan, kurang nyamannya ruang rawat, waktu tunggu saat pendaftaran yang lama, waktu menunggu dokter yang lama, karena terlalu banyak pasien sehingga komunikasi tidak baik dari perawat, dan belum semua petugas memakai tanda pengenal (papan nama).

\section{METODE}

Penelitian ini adalah penelitian kuantitatif bersifat komparatif. Populasi penelitian ini yaitu seluruh pasien rawat inap Rumah Sakit Grandmed Lubuk Pakam berdasarkan data sekunder didapat bahwa jumlah pasien rawat inap yang menggunakan BPJS dan cara pembayaran umum. Teknik pengambilan sampel dengan purposive sampling dengan jumlah sampel 324 orang.

\section{HASIL}


Tabel 1. Kategori Responden

Berdasarkan Kepuasan Pasien BPJS dengan Pasien Umum

\begin{tabular}{|c|c|c|c|c|}
\hline \multirow[t]{2}{*}{ Kategori } & \multicolumn{2}{|c|}{$\begin{array}{c}\text { Pasien } \\
\text { BPJS }\end{array}$} & \multicolumn{2}{|c|}{$\begin{array}{l}\text { Pasien } \\
\text { Umum }\end{array}$} \\
\hline & $\mathbf{n}$ & $\%$ & $\mathbf{n}$ & $\%$ \\
\hline \multicolumn{5}{|c|}{$\begin{array}{l}\text { Kepuasan Pasien } \\
\text { Berdasarkan Bukti } \\
\text { Fisik (Tangible) }\end{array}$} \\
\hline Baik & 133 & 82,1 & 119 & 73,5 \\
\hline Tidak Baik & 29 & 17,9 & 43 & 26,5 \\
\hline Total & 162 & 100,0 & 162 & 100,0 \\
\hline \multicolumn{5}{|l|}{$\begin{array}{l}\text { Kepuasan Pasien } \\
\text { Berdasarkan } \\
\text { Kehandalan } \\
\text { (Reliability) }\end{array}$} \\
\hline $\begin{array}{l}\text { Baik } \\
\text { Tidak Baik }\end{array}$ & $\begin{array}{c}126 \\
36\end{array}$ & $\begin{array}{l}77,8 \\
22,2\end{array}$ & $\begin{array}{c}110 \\
52\end{array}$ & $\begin{array}{l}67,9 \\
32,1\end{array}$ \\
\hline Total & 162 & 100,0 & 162 & 100,0 \\
\hline \multicolumn{5}{|c|}{$\begin{array}{l}\text { Kepuasan Pasien } \\
\text { Berdasarkan Daya } \\
\text { Tanggap } \\
\text { (Responsiveness) }\end{array}$} \\
\hline Baik & 136 & 84 & 105 & 64,8 \\
\hline Tidak Baik & 26 & 22,2 & 57 & 35,2 \\
\hline Total & 162 & 100,0 & 162 & 100,0 \\
\hline \multicolumn{5}{|c|}{$\begin{array}{l}\text { Kepuasan Pasien } \\
\text { Berdasarkan Jaminan } \\
\text { (Assurance) }\end{array}$} \\
\hline $\begin{array}{l}\text { Baik } \\
\text { Tidak Baik }\end{array}$ & $\begin{array}{c}137 \\
25\end{array}$ & $\begin{array}{l}84,6 \\
15,4 \\
\end{array}$ & $\begin{array}{c}123 \\
39\end{array}$ & $\begin{array}{l}75,9 \\
24,1 \\
\end{array}$ \\
\hline Total & 162 & 100,0 & 162 & 100,0 \\
\hline \multicolumn{5}{|c|}{$\begin{array}{l}\text { Kepuasan Pasien } \\
\text { Berdasarkan Empati } \\
\text { (Empathy) }\end{array}$} \\
\hline Baik & 142 & 87,7 & 121 & 74,7 \\
\hline Tidak Baik & 20 & 12,3 & 41 & 23,3 \\
\hline Total & 162 & 100,0 & 162 & 100,0 \\
\hline
\end{tabular}

Tabel 1 menunjukkan bahwa pada pasien BPJS kepuasan pasien berdasarkan bukti fisik (tangible) dalam kategori puas berjumlah 133 orang $(82,1 \%)$, kepuasan pasien berdasarkan kehandalan (reliability) berjumlah 126 orang $(77,8 \%)$, kepuasan pasien berdasarkan daya tanggap (responsiveness) berjumlah 136 orang $(84,0 \%)$, kepuasan pasien berdasarkan jaminan (assurance) berjumlah 137 orang $(84,6 \%)$, kepuasan pasien berdasarkan empati (empathy) berjumlah 142 orang $(87,7 \%)$. Pada pasien umum kepuasan pasien berdasarkan bukti fisik (tangible) berjumlah 119 orang atau (73,5\%), kepuasan pasien berdasarkan kehandalan (reliability) berjumlah 110 orang $(67,9 \%)$, kepuasan pasien berdasarkan daya tanggap (responsiveness) berjumlah 105 orang $(64,8 \%)$, kepuasan pasien berdasarkan jaminan (assurance) berjumlah 123 orang $(75,9 \%)$, kepuasan pasien berdasarkan empati (empathy) berjumlah 121 orang $(74,7 \%)$.

Tabel 2. Perbedaan Tingkat Kepuasan Pasien Badan Penyelenggara Jaminan Sosial Dengan Pasien Umum Berdasarkan Bukti Fisik (Tangible)

\begin{tabular}{|c|c|c|c|c|}
\hline $\begin{array}{l}\text { Kepuasan } \\
\text { Pasien } \\
\text { Berdasarkan } \\
\text { Bukti Fisik } \\
\text { (Tangible) }\end{array}$ & $n$ & Mean & SD & p. value \\
\hline Pasien BPJS & 162 & 33,31 & 4,926 & \multirow{2}{*}{0,001} \\
\hline Pasien Umum & 162 & 17,73 & 4,326 & \\
\hline
\end{tabular}

Tabel 2 menjelaskan bahwa berdasarkan hasil analisis diperoleh nilai $p<0,05 \quad(p=0,001)$, artinya ada perbedaan tingkat kepuasan pasien BPJS dengan pasien umum berdasarkan bukti fisik (tangible).

Tabel 3. Perbedaan Tingkat Kepuasan Pasien Badan Penyelenggara Jaminan Sosial Dengan Pasien Umum Berdasarkan Kehandalan (Reliability)

\begin{tabular}{|c|c|c|c|c|}
\hline $\begin{array}{l}\text { Kepuasan } \\
\text { Pasien } \\
\text { Berdasarkan } \\
\text { Kehandalan } \\
\text { (Reliability) }\end{array}$ & $n$ & Mean & SD & p. value \\
\hline Pasien BPJS & 162 & 33,43 & 4,844 & \multirow{2}{*}{0,001} \\
\hline Pasien Umum & 162 & 17,81 & 4,632 & \\
\hline
\end{tabular}

Tabel 3 menjelaskan bahwa berdasarkan hasil analisis diperoleh nilai $p<0,05 \quad(p=0,001)$, artinya ada perbedaan tingkat kepuasan pasien BPJS dengan pasien umum berdasarkan kehandalan (reliability).

Tabel 4. Perbedaan Tingkat Kepuasan Pasien Badan Penyelenggara Jaminan Sosial Dengan Pasien Umum Berdasarkan Daya Tanggap (Responsiveness) 
Jurnal Kesehatan Masyarakat \& Gizi, e-ISSN: 2655-0849

Vol. 3 No. 2 Edisi November 2020 - April 2021

https://ejournal.medistra.ac.id/index.php/JKG

Received: 28 April 2021 :: Accepted: 30 April 2021 :: Published: 30 April 2021

\begin{tabular}{lcccc}
\hline $\begin{array}{l}\text { Kepuasan Pasien } \\
\text { Berdasarkan } \\
\begin{array}{l}\text { Daya Tanggap } \\
\text { (Responsiveness) }\end{array}\end{array}$ & $\mathrm{n}$ & Mean & SD & p. value \\
\hline Pasien BPJS & 162 & 33,37 & 5,074 & 0,006 \\
Pasien Umum & 162 & 16,87 & 2,359 & \\
\hline
\end{tabular}

Tabel 4 menjelaskan bahwa berdasarkan hasil analisis diperoleh nilai $p<0,05 \quad(p=0,006)$, artinya ada perbedaan tingkat kepuasan pasien BPJS dengan pasien umum berdasarkan daya tanggap (responsiveness).

Tabel 5. Perbedaan Tingkat Kepuasan Pasien Badan Penyelenggara Jaminan Sosial Dengan Pasien Umum Berdasarkan Jaminan (Assurance)

\begin{tabular}{|c|c|c|c|c|}
\hline $\begin{array}{l}\text { Kepuasan Pasien } \\
\text { Berdasarkan } \\
\text { Jaminan } \\
\text { (Assurance) }\end{array}$ & $\mathrm{n}$ & Mean & SD & p. value \\
\hline Pasien BPJS & 162 & 33,49 & 4,993 & \multirow{2}{*}{0,009} \\
\hline Pasien Umum & 162 & 16,84 & 2,367 & \\
\hline
\end{tabular}

Tabel 5 menjelaskan bahwa berdasarkan hasil analisis diperoleh nilai $p<0,05 \quad(p=0,009)$, artinya ada perbedaan tingkat kepuasan pasien BPJS dengan pasien umum berdasarkan jaminan (assurance).

Tabel 6. Perbedaan Tingkat Kepuasan Pasien Badan Penyelenggara Jaminan Sosial Dengan Pasien Umum Berdasarkan Empati (Empathy)

\begin{tabular}{|c|c|c|c|c|}
\hline $\begin{array}{l}\text { Kepuasan } \\
\text { Pasien } \\
\text { Berdasarkan } \\
\text { Empati } \\
\text { (Empathy) }\end{array}$ & $n$ & Mean & SD & p. value \\
\hline Pasien BPJS & 162 & 33,56 & 4,956 & \multirow{2}{*}{0,002} \\
\hline Pasien Umum & 162 & 16,85 & 2,379 & \\
\hline
\end{tabular}

Tabel 6 menjelaskan bahwa berdasarkan hasil analisis diperoleh nilai $p<0,05 \quad(p=0,002)$, artinya ada perbedaan tingkat kepuasan pasien BPJS dengan pasien umum berdasarkan empati (empathy).

\section{PEMBAHASAN}

Bukti langsung (tangible) mutu pelayanan kesehatan dapat dirasakan oleh para penggunanya secara langsung untuk menilai mutu dari layanan kesehatan. Dimensi tangible pada penelitian ini meliputi kerapian, kebersihan, kenyamanan ruang periksa dan ruang tunggu, kesediaan dan kelengkapan alat-alat kesehatan serta alat penunjang, ketersedian sarana parkir dan penampilan petugas.

Berdasarkan hasil analisis diperoleh nilai $p$ value sebesar 0,001 yang artinya ada perbedaan tingkat kepuasan pasien BPJS dengan pasien umum berdasarkan bukti fisik. Hal ini sejalan dengan hasil penelitian perbandingan kepuasan pasien peserta ASKES sukarela dan wajib di Rumah sakit dengan dokter keluarga di Sulawesi Tenggara, bahwa dari segi penampilan fisik ruang pemeriksaan, kenyamanan ruang tunggu pada dokter keluarga lebih baik daripada Rumah sakit (Nurkholiq, 2011).

Kehandalan (reliability) meliputi kemampuan memberikan pelayanan dengan segera, terpercaya, akurat, sesuai dengan yang telah dijanjikan dan bersikap simpati kepada pelanggan. Persepsi kehandalan pada penelitian ini meliputi kecepatan prosedur pendaftaran, waktu tunggu, ketepatan jadwal pelayanan dan ketepatan pemeriksaan.

Berdasarkan hasil analisis diperoleh nilai $p$ value sebesar 0,001 yang artinya ada perbedaan tingkat kepuasan pasien BPJS dengan pasien umum berdasarkan kehandalan (reliability). Terdapat ketidakpuasan responden pada aspek dimensi kehandalan (reliability) atas waktu tunggu untuk mendapatkan pelayanan. Kepuasan pasien dapat dilihat dari prosedur layanan yang cepat, tidak berbelit- belit sehingga konsumen tidak menunggu lama untuk mendapatkan layanan (Allo, 2013). Harapan pasien terhadap 
kecepatan pelayanan cenderung meningkat dari waktu ke waktu, dimana nilai waktu bagi pasien semakin mahal karena kegiatan ekonominya semakin meningkat (Muninjaya, 2011).

Ketidakpuasan responden pada aspek dimensi kehandalan (reliability) atas ketepatan jadwal pelayanan yang meliputi jadwal buka dan tutup pelayanan. Pasien yang datang ke pelayanan kesehatan adalah seseorang yang dalam kondisi sakit dan membutuhkan pertolongan, sehingga menginginkan segera dilayani. Apabila pasien harus menunggu dokter ataupun pelayanan sudah tutup sebelum waktunya akan memicu timbulnya ketidakpuasan.

Daya tanggap (responsiveness) merupakan keinginan dan kemampuan dalam memberikan pelayanan yang tanggap, cepat, tepat waktu dan tidak lama kepada pelanggannya. Persepsi daya tanggap pada penelitian ini meliputi ketanggapan, kecepatan, kejelasan informasi tentang penyakit, tindakan dan pemakaian obat.

Berdasarkan hasil analisis diperoleh nilai $p$ value sebesar 0,006 yang artinya ada perbedaan tingkat kepuasan pasien BPJS dengan pasien umum berdasarkan daya tanggap (responsiveness). Hasil penelitian ini sejalan dengan penelitian Wiyono (2008) menyatakan bahwa pelayanan yang baik akan memberikan kepuasan kepada pelanggannya. Di dalam penelitian yang dilakukan Wiyono, menunjukan bahwa semua variabel kualitas pelayanan dengan indikator keandalan, daya tangkap, kepastian, empati, dan bukti fisik secara signifikan memiliki pengaruh terhadap kepuasan pasien di RS Islam Manisrenggo Klaten.

Ketanggapan dokter dan petugas dalam memberikan layanan kesehatan mempengaruhi kepuasan pasien dimana, petugas dituntut untuk segera merespon dan memberikan informasi terkait penyakit, tindakan maupun pemberian obat. Pemberian informasi terkait dengan kepatuhan pasien dalam pengobatan dan mampu untuk melakukan pencegahan tetapi jika informasi yang diberikan tidak jelas akan menyebabkan pasien tidak puas, terlebih informasi tersebut semakin sulit didapatkan ketika pasien sudah keluar dari tempat layanan tersebut.

Berdasarkan hasil analisis diperoleh nilai $p$ value sebesar $p=0,009$ yang artinya ada perbedaan tingkat kepuasan pasien BPJS dengan pasien umum berdasarkan jaminan (assurance).

Pada dasarnya pasien menginginkan kesinambungan dengan petugas kesehatan artinya ingin dilayani dengan petugas kesehatan yang sama (Pohan, 2010). Terdapat ketidakpuasan responden pada aspek dimensi jaminan (assurance) karena pasien harus datang berulang kali dan pindah ke tempat layanan kesehatan lainnya untuk mendapatkan kesembuhan. Kepuasan pasien terhadap mutu layanan dinyatakan oleh sikap terhadap kompetensi teknik dokter dan petugas serta keluaran atau perubahan yang dirasakan oleh pasien sebagai hasil dari layanan kesehatan yang diterima. Pasien yang mendapatkan pelayanan kesehatan oleh petugas yang kompeten dan mendapatkan keluaran berupa kesembuhan merupakan hal utama yang diinginkan oleh pasien.

Peneliti berasumsi bahwa jaminan (assurance) adalah bagian dari kenyamanan pasien, jika pasien merasa nyaman maka mereka akan datang kembali, antara pasien dan pegawai tidak bersahabat sehingga membuat suasana kurang nyaman. Pasien umum berpendapat bahwa Ketrampilan petugas kesehatan dalam memberikan pelayanan kepada pasien kurang seperti menyuntik obat lebih 
sering dilaukan leh mahasiswa, menjahit luka dilakukan di ruang IGD. Terdapat sebagian dokter yang tidak ramah dalam memberikan pelayanan kesehatan. Patugas kesehatan tidak memberikan penjelasan pengobatan dan pendidikan yang akan dilakukan saat pasien kembali kerumah (Discharge Planning). Terdapat petugas yang tidak memberikan motivasi untuk kesembuhan pasien. Dokter dan petugas tidak berkomunikasi dengan pasien secara baik, hal tersebut dikarenakan jumlah pasien yang banyak.

Dimensi perhatian (empathy) yaitu kriteria yang berkaitan dengan kepedulian dan perhatian kepada setiap pelanggan, memahami kebutuhan mereka dan bisa dihubungi pelanggan yang membutuhkan bantuan. Dimensi perhatian (empathy) dalam penelitian ini meliputi ketersediaan waktu luang petugas untuk berkomunikasi dengan pasien, kesabaran petugas dan perhatian petugas.

Berdasarkan hasil analisis diperoleh nilai $p$ value sebesar $p=0,002$ yang artinya ada perbedaan tingkat kepuasan pasien BPJS dengan pasien umum berdasarkan empati (empathy). Ketidakpuasan responden meliputi kurangnya ketersediaan waktu untuk komunikasi dengan pasien dan kurangnya perhatian dokter terhadap keluhan pasien. Ketidakpuasan pasien pada dimensi perhatian (empathy) di Rumah sakit kemungkinan karena tingginya kunjungan pasien sehingga perhatian petugas tidak maksimal ke pasien.

Hasil penelitian tidak sejalan dengan penelitian Rattu (2015) menyatakan ada pengaruh positif antara komunikasi dokter terhadap kepuasan pasien rawat jalan. Namun sejalan dengan penelitian Resnani (2012) menyatakan ada pengaruh positif antara komunikasi dokter terhadap kepuasan pasien rawat jalan.

\section{KESIMPULAN}

Kesimpulan pada penelitian ini yaitu:

a. Terdapat perbedaan tingkat kepuasan pasien badan penyelenggara jaminan sosial dengan pasien umum berdasarkan bukti fisik (tangible) dengan nilai $\mathrm{p}=0,001$.

b. Terdapat perbedaan tingkat kepuasan pasien badan penyelenggara jaminan sosial dengan pasien umum berdasarkan kehandalan (reliability) dengan niali $\mathrm{p}=0,001$.

c. Terdapat perbedaan tingkat kepuasan pasien badan penyelenggara jaminan sosial dengan pasien umum berdasarkan daya tanggap (responsiveness) dengan niali $p=0,006$.

d. Terdapat perbedaan tingkat kepuasan pasien badan penyelenggara jaminan sosial dengan pasien umum berdasarkan jaminan (assurance) dengan niali $\mathrm{p}=0,009$.

e. Terdapat perbedaan tingkat kepuasan pasien badan penyelenggara jaminan sosial dengan pasien umum berdasarkan empati (empathy) dengan niali $p=0,002$.

\section{DAFTAR PUSTAKA}

Allo, I.L., Darmawansyah \& Hamzah, A., 2013. Studi Kualitas Pelayanan Kesehatan Bagi Pasien Rawat Inap Peserta Asuransi Kesehatan di Rumah Sakit Elim Rantepao tahun 2013. Universitas Hasanuddin Makasar.

Direktorat Jaminan Sosial Nasional (DJSN), K., 2012. Peta Jalan Menuju 
Jaminan Kesehatan Nasional 20122019, Jakarta.

Fidella, Firwan Firdaus. 2015. Evaluasi Kualitas Pelayanan Terhadap Kepuasan Pasien Rawat Jalan Peserta BPJS di RSUD Panembahan Senapati Bantul, Megister Manajemen Rumah Sakit, Universitas Muhamadiyah Yogyakarta

Hidayat, B., 2010. Bukti Empiris Kebijakan Asuransi Kesehatan Sosial: Analisis Survei Aspek Kehidupan Rumah Tangga Indonesia (Sakerti). Jurnal Manajemen Pelayanan Kesehatan, 13(03), pp.117-125.

Kemenkes RI, 2014. Pedoman Pelaksanaan Program Jaminan Kesehatan Nasional.

Muninjaya, 2011. Manajemen Mutu Pelayanan Kesehatan, Jakarta: EGC.

Nurkholiq, S., 2011. Perbandingan Tingkat Kepuasan Pasien Umum Dengan Penggunaan Kartu Askes di Pelayanan Dokter Keluarga PT Askes. Universitas Diponegoro.

Notoatmodjo, Soekidjo. 2010. Metodologi Penelitian Kesehatan. Jakarta: Rineka Cipta

Pohan, I., 2010. Jaminan Mutu Layanan Kesehatan Dasar-dasar Pengertian dan Penerapan, Jakarta: EGC.

Rattu, et. al. 2015. Perbedaan Kualitas Pelayanan Keperawatan Terhadap Pasien Penerima Bantuan Iuran Dan Pasien Bukan Penerima Bantuan Iuran. Jurnal, Program Studi IImu Keperawatan Fakultas Kedokteran Universitas Sam Ratulangi

Sabarguna, B.S. 2010. Quality Assurance Pelayanan Rumah Sakit. Edisi Kedua. Yogyakarta: Konsorsium Rumah Sakit Islam Jateng-DIY

Wiyono, Aziz Selamet, 2008. Studi Tentang Kualitas Pelayanan dan Kepuasaan Konsumen di Rumah
Sakit Islam Manisrenggo Klaten. Tesis. Universitas Muhammadiyah Surakarta. 